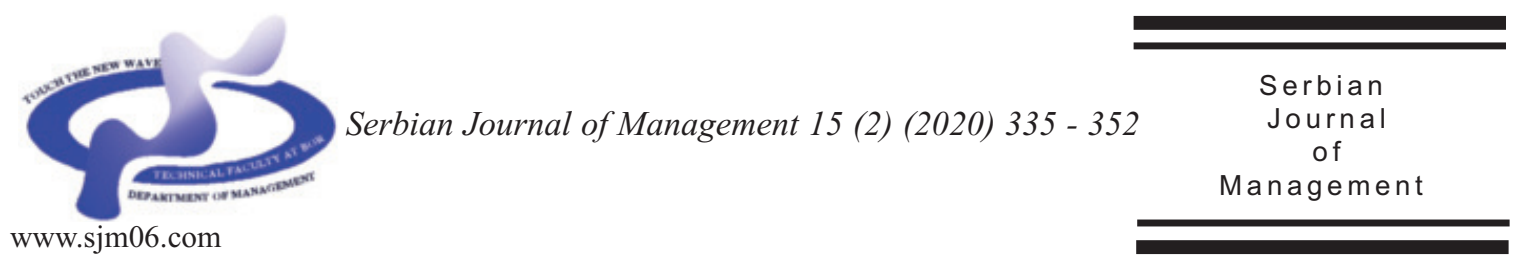

\title{
THE ROLE AND IMPORTANCE OF LARGE COMPANIES IN THE ECONOMY OF THE REPUBLIC OF SERBIA
}

\author{
Saša Krstić and Aleksandra Fedajev* \\ University in Belgrade, Technical faculty in Bor, Vojske Jugoslavije 12, 19210 Bor, Serbia
}

(Received 30 December 2018; accepted 24 January 2019)

\begin{abstract}
In contemporary business conditions, advanced market economies are characterized by the increasing contribution of the SMEs sector to the economic development. Having that in mind, a large number of papers have been aimed at analyzing business doing in this sector in the last couple of years. In this way, the focus has been shifted from large business entities and their importance to the economic growth to the SMEs sector. In this regard, the aim of this paper is to examine the financial situation, the place and the role of large companies in the overall economy of the Republic of Serbia, where, having in mind the fact that it is a transition economy, large enterprises, both private and public, significantly contribute to the growth of the economic activity and employment. Before all, the degree of the liquidity, efficiency, indebtedness and profitability of these companies in the period 2014-2017 was determined by using the ratio analysis. After that, on the basis of the selected ratios, a comparative financial performance analysis of large business entities in relation to those small, medium-sized and micro- was carried out by applying the Entropy and the PROMETHEE II methods. The obtained results pointed out that large business entities had a favorable business economy in relation to the other groups of business entities by size, and their performances had improved to a certain extent in the observed period.
\end{abstract}

Keywords: large business entities, ratio analysis, Entropy method, PROMETHEE II method

\section{INTRODUCTION}

According to the Accounting Law of 2013, legal entities are classified into micro, small, medium-sized and large, depending on the average number of employees, operating income and the average value of operating assets determined on the date of the compilation of the regular annual financial report at the end of the financial year.

Large business entities have the following characteristics (Accounting Law, 2013), namely they:

\footnotetext{
*Corresponding author: afedajev@tfbor.bg.ac.rs
}

DOI: $10.5937 /$ sjm15-19553 
1. employ over 250 workers,

2. have assets amounting over EUR $17,500,000$, and

3. generate high total income exceeding EUR 35,000,000.

In addition to this, large business entities also have a number of other characteristics (Nikolić \& Fedajev, 2016), namely they:

1. apply modern science and technology in business,

2. are not flexible,

3. their production is mainly specialized,

4. have a wide range of business functions, and

5. are usually the drivers of development in the broader area in which they operate (the region).

In the last few decades, a large number of authors have emphasized the fact that the development of the SMEs sector has a crucial role for the development of any national economy, especially so in transition economies, such as the Serbian economy is. In this regard, most papers in this field are predominantly focused on the analysis of this sector, whereas the place, the role and the importance of large economic systems are to a certain extent neglected (Đalić et al., 2017; Březinovă \& Průšovă, 2014; Jakopin, 2015). Moreover, a picture has been created that, in the Serbian economy, the largest part of this segment of the economy consists of inefficient large state-owned enterprises with a high number of employees, which as such do not represent what they should actually be - the driver of economic development. In addition, the fact that a large amount of funds from the state budget goes to their artificial maintenance, instead of having these funds directed towards the SMEs sector, which would lead to a faster revival of the economic activity, is emphasized (Aničić et al., 2017; Anđelković, 2017; Paunović, 2017).

Table 1 shows the data on the share of large enterprises in the total number of enterprises and the total number of employees in the Republic of Serbia for the period from 2014 to 2017.

Based on Table 1, it can be concluded that the number of large companies in Serbia in the observed period is relatively stable. The highest number of these enterprises were recorded in the year 2014, and by the year 2017, a slight decrease was recorded. It is important to note that large companies in Serbia have a very low share in the total number of economic entities. It amounted to $0.36 \%$ in 2014 , and, as the total number of the enterprises increased and the number of large business entities decreased, this share decreased to $0.31 \%$ in 2017 .

Table 1. The share of large enterprises in the total number of economic entities and the total number of employees, assets, equity and operating income in the Republic of Serbia in the period from 2014 to 2017

\begin{tabular}{lcccc}
\hline \multicolumn{1}{c}{ Indicators } & $\mathbf{2 0 1 4}$ & $\mathbf{2 0 1 5}$ & $\mathbf{2 0 1 6 .}$ & $\mathbf{2 0 1 7 .}$ \\
\hline Share in total number of enterprises (in \%) & 0,36 & 0,33 & 0,31 & 0,31 \\
Share in total number of employees (in \%) & 31,21 & 29,88 & 29,45 & 29,69 \\
Shere in total assets (in \%) & 50,19 & 46,63 & 44,54 & 45,20 \\
Shere in total equity (in \%) & 57,05 & 52,77 & 50,77 & 52,80 \\
Shere in total operating income (in \%) & 45,26 & 40,90 & 41,16 & 41,78 \\
\hline
\end{tabular}

Source: Financial statements annual bulletin. 
The fact that large economic entities account for a low share in the total number of enterprises does not necessarily mean that they have small importance in the Serbian economy. Their importance is primarily reflected in the share in the total number of employees, assets, equity and operating income. The highest number of employees in large enterprises was recorded in 2017, whereas the largest share in the total employment was recorded in 2014, amounting to $31.21 \%$. In 2017, this percentage was $29.69 \%$, which is a result of an increase in the total employment at the level of the Serbian economy as a whole. Thus, despite the exceptionally small share of large companies in their total number of enterprises, the enormous importance to the Serbian economy is more than evident, bearing in mind the fact that they absorb almost one-third of the employees. In 2017, these enterprises contributed to the total assets of the economy by $45.20 \%$, the total equity by $52.80 \%$, and operating income by $41.78 \%$, as a result of a larger growth of the total assets, equity and operating income in the economy than in large enterprises.

Privatization and increasing FDIs inflow into the Serbian economy as a result of a more favorable business climate made a great contribution to such developments. The privatization process was intensified after 2003, only to slow down as time passed, so, only a small number of large enterprises were privatized in the observed period, namely Galenika, C Market, HBIS GROUP Serbia Iron \& Steel, etc. (Ministry of Economy in the Republic of Serbia). A similar trend was recorded in FDIs as well. The FDIs inflow was very high after 2003, especially in the period 2006-2008, and in 2011 (Stojanović, 2018; Kastratović, 2016).

Based on all of the foregoing, the paper is aimed at determining the financial performances of large enterprises and the changes that occurred in their business doing in the period 2014-2017, as well as the examining of their position in relation to the remaining types of business entities by their size by the application of the PPROMETHEE and the Entropy methods.

\section{A FINANCIAL ANALYSIS OF LARGE ENTERPRISES}

Financial analysis is a very important segment of financial management which enables the assessment of the financial status of a company and the making of quality strategic decisions. During the last few decades, business entities have been faced with numerous challenges and the assessment of their performances has become more complex. In that sense, the technics of financial analysis have been significantly improved in order to identify a company's limitations and propose the measures for overcoming them, with the aim of avoiding their effects in the future (Filipović \& Marjanić, 2016). The elements of financial analysis used the most are:

1. Balance Sheet analysis,

2. Profit and Loss Account analysis, and

3. ratio analysis.

These aspects of financial analysis are used to assess the financial position of large enterprises in Republic of Serbia.

\subsection{Balance sheet analysis}

Balance Sheet analysis is aimed at assessing the value and structure of assets and sources in a company. In order to identify changes in the assets of large enterprises in the Republic of Serbia during 
Table 2. The structure of large enterprises' assets in 2014 and 2017

\begin{tabular}{lccc}
\hline \multicolumn{1}{c}{ Description } & $\mathbf{2 0 1 4 .}$ & $\mathbf{2 0 1 7 .}$ & Index \\
\hline ASSETS & & & \\
\hline Subscribed capital unpaid & 836.478 & 69.933 & 8,36 \\
Permanent assets & 4.412 .537 .016 & 4.633 .102 .555 & 105,00 \\
Intangible assets & 150.097 .726 & 193.681 .946 & 129,04 \\
Immovables, plants and equipment & 3.511 .953 .603 & 3.885 .985 .583 & 110,65 \\
Biological resources & 65.317 .446 & 155.077 .914 & 237,42 \\
Long-term fnancial investments & 666.491 .304 & 388.839 .313 & 58,34 \\
Long-term receivables & 18.676 .937 & 9.517 .799 & 50,96 \\
Deferred tax assets & 26.036 .075 & 19.011 .972 & 73,02 \\
Current assets & 1.823 .304 .252 & 1.765 .811 .926 & 96,85 \\
Inventories & 502.469 .097 & 550.455 .652 & 109,55 \\
Receivables from sale & 746.524 .142 & 645.251 .517 & 86,43 \\
Short-term fnancial investments & 169.524 .108 & 122.449 .383 & 72,23 \\
Cash and cash equivalents & 168.381 .796 & 242.255 .466 & 143,87 \\
Total assets $=$ Operating assets & $\mathbf{6 . 2 6 2 . 7 1 3 . 8 2 1}$ & $\mathbf{6 . 4 1 7 . 9 9 6 . 3 8 6}$ & $\mathbf{1 0 2 , 4 8}$ \\
Off-balance sheet assets & 936.302 .724 & 1.086 .297 .845 & 116,02 \\
\hline
\end{tabular}

Source: Financial statements annual bulletin.

the period 2014-2017, the structure of the assets in the years 2014 and 2017 is presented in Table 2.

Table 2 reflects the obvious fact that permanent assets contributed to the total assets by $70.46 \%$, and most of those assets are immovables, plants and equipment $(79.59 \%)$. On the other hand, the greatest share in current assets was that accounted for by the receivables from sale, as much as $40.94 \%$, whereas the share of cash and cash equivalents amounted to $9.19 \%$, indicating that those enterprises had problems with collecting receivables in 2014.

There are no significant changes in the structure of permanent assets in comparison with the year 2014. Immovables, plants and equipment still have the greatest share in the total assets $(83.87 \%)$. As can be noted, this share is somewhat increased (5.38\%), as well as the value of these assets (10.65\%), indicating investment in the capacities expansion.

There are some interesting changes in the structure of current assets. Although the value of those assets was somewhat lower in comparison to 2014 (3.15\%), the share of the receivables from sale reduced to $37.05 \%$, whereas the share of cash and cash equivalents increased to $13.72 \%$. Such developments are indicative of the fact that the efficiency of the receivables collection improved to some extent.

Beside the structure of assets, a quality financial analysis necessarily requires the assessment of the structure of the equity and liabilities of large enterprises in 2014 and 2017, which is shown in Table 3.

The data demonstrated in Table 3 indicate that large enterprises had a relatively favorable structure of their respective equity and liabilities in 2014, bearing in mind the fact that their equity contributed $51.87 \%$ to the total financial sources of the assets. When the structure of liabilities is concerned, it can be noted that short-term liabilities had the biggest share in the total liabilities (74.81\%), indicating that those 
Table 3. The structure of the equity and liabilities of large enterprises in 2014 and 2017

\begin{tabular}{lccc}
\hline \multicolumn{1}{c}{ Description } & $\mathbf{2 0 1 4 .}$ & $\mathbf{2 0 1 7 .}$ & Index \\
\hline EQUITY AND LIABILITIES & & & \\
\hline Equity & 3.248 .413 .137 & 3.660 .282 .344 & 112,68 \\
Long-term provisions and liabilities & 1.128 .098 .729 & 1.053 .938 .046 & 93,43 \\
Long-term provisions & 63.625 .976 & 64.872 .983 & 101,96 \\
Long-term liabilities & 1.064 .472 .753 & 989.065 .063 & 92,92 \\
Deferred tax liabilities & 139.863 .172 & 155.959 .103 & 111,51 \\
Short-term liabilities & 2.254 .934 .584 & 1.920 .446 .603 & 85,17 \\
Short-term fnancial liabilities & 681.427 .295 & 605.959 .588 & 88,93 \\
Operating liabilities & 954.770 .085 & 741.821 .313 & 77,70 \\
Other short-term liabilities & 618.737 .204 & 169.349 .647 & 27,37 \\
Loss above equity & 508.595 .801 & 372.629 .710 & 73,27 \\
Total equity and liabilities & $\mathbf{6 . 2 6 2 . 7 1 3 . 8 2 1}$ & $\mathbf{6 . 4 1 7 . 9 9 6 . 3 8 6}$ & 102,48 \\
Off-balance sheet liabilities & 936.302 .724 & 1.086 .297 .845 & 116,02 \\
\hline
\end{tabular}

Source: Financial statements annual bulletin.

companies used borrowed sources to maintain their current liquidity.

In 2017, large enterprises increased the share of equity in the total sources $(57.03 \%)$. The largest portion of this capital belongs to large companies operating in the electricity, gas, steam and air-conditioning supply sector $(33.85 \%)$. The structure of the borrowed assets did not change to a great extent. In addition, it is worth noting that the share of short-term liabilities was reduced to $69.64 \%$.

\subsection{Profit and Loss Account Statement Analysis}

In order to take an insight into the financial performances of large enterprises, the Profit and Loss Account for the years 2014 and 2017 is presented in Table 4.

Table 4 indicates that in 2014 large enterprises recorded a negative net result amounting to RSD 79 billion, accounting for $60 \%$ of the negative net financial result of the economy in 2014. Large enterprises operating in the transportation and storage sector mostly contributed to the recorded negative net result. In addition, it is interesting to emphasize the fact that such a high negative net result was recorded due to a high loss from financing (resulting from an increase in the negative effects of the exchange rate and interest expenses) and other activities.

In 2017, large enterprises improved their financial result in comparison with 2014. They recorded a positive net result amounting to RSD 253.2 billion in 2017 , thus greatly contributing to the profitability improvement in the Serbian economy, bearing in mind the fact that the positive net result recorded by these enterprises accounts for $45.8 \%$ of the total positive net result, and $85.9 \%$ of the enterprises recorded a net profit at the end of 2017. The enterprises operating in the manufacturing sector had the biggest share in the positive net result (47.7\%).

A better financial position in 2017 is, first of all, a result of the achieved profit from financing due to an increase in the positive effects on the exchange rate, and a decrease in the negative effects on the exchange rate. It should be mentioned that the positive result from financing is higher than the total net result of the economy as a whole. In addition, large enterprises increased their operating profit by $32.84 \%$, and the result from their other activities by $67.63 \%$. 
Table 4. The Profit and Loss Account of large enterprises in the Republic of Serbia for 2014 and 2017

\begin{tabular}{lccc}
\hline \multicolumn{1}{c}{ Description } & $\mathbf{2 0 1 4 .}$ & $\mathbf{2 0 1 7 .}$ & Index \\
\hline Total income & 4.042 .165 .923 & 4.434 .231 .814 & 109,70 \\
Total expenses & 4.103 .225 .254 & 4.148 .253 .260 & 101,10 \\
Operating income & 3.825 .247 .464 & 4.169 .877 .783 & 109,01 \\
Operating expenses & 3.642 .118 .816 & 3.926 .618 .687 & 107,81 \\
Operating result & 183.128 .648 & 243.259 .096$. & 132,84 \\
Financial income & 126.676 .189 & 142.946 .362 & 112,84 \\
Financial expenses & 248.152 .570 & 103.233 .924 & 41,60 \\
Result from finansing & -121.476 .381 & 39.712 .438 & 405,89 \\
Other income & 72.160 .143 & 102.316 .975 & 141,79 \\
Other expense & 101.213 .316 & 59.360 .428 & 58,65 \\
Result from other activities & -29.053 .173 & 42.956 .547 & 167,63 \\
Proft from regular business operations before tax & 189.041 .070 & 334.787 .249 & 177,10 \\
Loss from regular business operations before tax & 247.339 .588 & 48.594 .350 & 19,65 \\
ProfIt before tax & 188.911 .007 & 334.709 .839 & 177,18 \\
Loss before tax & 249.970 .338 & 48.731 .285 & 19,49 \\
Tax on profIt & 17.582 .778 & 32.236 .208 & 183,34 \\
Net profIt & 171.694 .385 & 302.095 .025 & 175,95 \\
Net loss & 250.716 .972 & 48.851 .975 & 19,48 \\
Positive net result & & $\mathbf{2 5 3 . 2 4 3 . 0 5 0}$ & \\
Negative net result & $\mathbf{7 9 . 0 2 2 . 5 8 7}$ & & \\
\hline
\end{tabular}

Source: Financial statements annual bulletin.

\subsection{Ratio Analysis}

Ratio analysis is a very useful tool for the assessment of a company's performances. It uses comparisons between different positions from the Balance Sheet and the Profit and Loss Account so as to take an insight into the certain aspects of business doing that are important for the formulation of business strategies and policies. In that sense, the ratio indicators for large enterprises that were most commonly used in 2014 and 2017 are given in Table 5.

Liquidity is certainly one of the most important aspects of the business economy. In that sense, the first group of the indicators in Table 5 are the liquidity ratios. The presented data indicate that, in 2017, the current ratio increased by $13.78 \%$, and the quick ratio increased by $7.55 \%$, that being so due to a greater decrease in the short-term liabilities than in working capital. Although this represented a significant improvement, a conclusion may be drawn that liquidity was not at a satisfactory level because both indicators were lower than 1 , indicating that the short-term liabilities were still higher than the working capital. Having in mind the different size of the considered enterprises, the net working capital was calculated per employee in order to obtain a comparable indicator. It can be noted that this indicator was negative and lower than in 2014 (by $65.77 \%$ ) due to the mentioned proportion between the short-term liabilities and the working capital, as well as to an increase in the number of the employees in these companies. All the considered indicators suggest that there were significant improvements in this field in large companies during the period 2014-2017, but they still have problems to maintain a satisfactory liquidity level.

When the activity ratios are concerned, the indicators presented in Table 5 suggest that 
Table 5. The ratio analysis of large enterprises in the Republic of Serbia in 2014 and 2017

\begin{tabular}{|c|c|c|c|}
\hline \multirow[b]{2}{*}{ Indicators } & \multicolumn{3}{|c|}{ Year } \\
\hline & 2014. & 2017. & Index \\
\hline \multicolumn{4}{|l|}{ Liquidity ratios } \\
\hline Current ratio - CR & 0,81 & 0,92 & 113,78 \\
\hline Quick ratio - QR & 0,59 & 0,63 & 107,55 \\
\hline Net working capital (per employee in 000 RSD) - NWC & $-1.417,00$ & $-485,11$ & 34,23 \\
\hline \multicolumn{4}{|l|}{ Activity ratios } \\
\hline Customer turnover coefficient - CTC & 4,97 & 6,30 & 126,76 \\
\hline Average collection period - ACP & 72,40 & 57,18 & 78,98 \\
\hline Fixed assets turnover - FAT & 0,87 & 0,90 & 103,45 \\
\hline Assets turnover - AT & 0,61 & 0,65 & 106,56 \\
\hline \multicolumn{4}{|l|}{ Profitability ratios } \\
\hline Operating profit margin (in \%) - OPM & 4,79 & 5,83 & 121,71 \\
\hline Net profit margin (in \%) - NPM & $-2,07$ & 6,07 & 134,10 \\
\hline ROA (in \%) & 2,92 & 3,79 & 129,79 \\
\hline ROE (in \%) & $-2,88$ & 7,70 & 137,40 \\
\hline Efficiency coefficient - EC & 0,99 & 1,07 & 108,08 \\
\hline \multicolumn{4}{|l|}{ Debt ratios } \\
\hline Debt ratio (in \%) - DR & 56,25 & 48,77 & 86,70 \\
\hline Debt to equity ratio DER & 1,29 & 0,95 & 73,64 \\
\hline
\end{tabular}

large business entities made a certain shift in 2017 compared to 2014 as all of the observed indicators improved. The customer turnover ratio increased by $26.76 \%$, while the receivables average collection period was 15 days shorter in the observed period as a result of an increase in the sales income and a decrease in the receivables from sale. In addition, there was a slight increase in the turnover of the fixed and the total assets in the observed period as a result of an increase in the sales income, while the value of the total assets and the share of the fixed assets in the total assets changed to a lesser extent.

The mentioned trends in the fields of liquidity and asset management certainly influenced the profitability of large enterprises, which is proven by the indicators from Table 5, having in mind the fact that all of the profitability ratios improved in the year 2017. The most obvious reason for such a trend is the fact that large business entities recorded a net profit in 2017, as opposed to 2014, when they had recorded a net loss. The operating profit rate increased by $21.71 \%$ (the operating result was positive in both observed years) and the net profit rate increased by $34.10 \%$. Although there was an increase in the total assets and equity, the rate of return on total assets and return on equity capital increased by $29.79 \%$ and $37.40 \%$ due to the positive net result of 2017 . Considering the fact that the growth of the total revenues exceeded the growth of the total expenditures, the efficiency coefficient also increased (by 8.08\%).

The only field where large enterprises worsened their position is debt management, having in mind the fact that both debt ratios declined - the debt ratio by $13.3 \%$ and $26.36 \%$. This decline indicated the worsening of the leverage and greater relying 
on borrowed sources, which can have longterm implications for the growth and development of these enterprises.

\section{METHODOLOGY}

The next step in the evaluation of the large enterprises' performances is the conducting of a comparative analysis amongst all the groups of the enterprises by size. Bearing in mind a large number of the criteria (ratios) that need to be considered in order to gain an insight into the business economy of these groups of enterprises, it can be concluded that such an analysis belongs to the domain of multi-criteria analysis. There are a large number of the papers focused on the application of the multi-criteria analysis methods in various scientific disciplines (Marasovic \& Babic, 2011; Araz \& Ozkarahan, 2007; Andreopoulou et al., 2018; Lopes et al., 2018), and various methods of multi-criteria analysis have been developed in order to make them more adjusted to the challenges faced by decision-makers in contemporary conditions (Ishizaka \& Nemery, 2013). In this paper, the PROMETHEE method is applied.

\subsection{PROMETHEE method}

One of the most prominent multi-criteria methods is certainly the PROMETHEE method, which is commonly used to solve multi-criteria problems, implying the ranking of the final set of alternatives, taking into consideration various criteria with a different direction of preferences. The value of each alternative (expressed in preferences) is calculated and it is called the net preferences flow. This indicator synthesizes all the observed criteria, and according to its value, observed alternatives are ranked (Tomić-Plazibat et al., 2010).

In order to perform the ranking of alternatives, the PROMETHEE method requires the definition of certain parameters for each criteria (Brans et al., 1984; Brans \& Vincke, 1985; Brans \& Mareschal, 2005; VP Solutions):

1. the preference direction, which implies whether certain criteria should be minimized or maximized;

2. weight coefficients, which indicate the importance of certain criteria;

3. the preference function, which converts the difference between two alternatives at the preference level (the following functions are available: Linear, V-shape, Usual, Level, Ushape and Gaussian);

4. the preference threshold $(p)$, which represents the minimum deviation that a decision-maker considers as significant for decision-making;

5. the indifference threshold $(q)$, which represents the maximum deviation that a decision-maker considers as irrelevant for decision-making;

6. the $\mathrm{S}$ threshold, which represents the value between $q$ and $p$, and is used for the Gaussian preference function.

The PROMETHEE II methodology consists of the following steps:

1. Step one implies a comparison of each pair of alternatives for the $j$ criteria and the calculation of the deviation $d_{j}$. If one considers the deviation between the alternatives $a$ and $b$, then

$$
d_{j}(a, b)=g_{j}(a)-g_{j}(b)
$$

where $d_{j}(a, b)$ represents the advantage of the alternatives $a$ and $b$ according to each criterion. If this deviation is too low, there is 
a justified reason to claim that the alternative $a$ is better than the alternative $b$. On the other hand, if that difference exceeds a certain limit, the decision-maker may strictly prefer the alternative $\mathrm{a}$ in relation to the alternative b. In order to model these statements, the difference $d_{j}(a, b)$ is transformed into a synthetic indicator - the preference level, by using the appropriate preference function;

2. In the next step, the chosen preference function is applied:

$$
P_{j}(a, b)=F_{j}\left[d_{j}(a, b)\right]
$$

where $P_{j}(a, b)$ represents the preference of the alternative $a$ in comparison with the alternative $b$ according to all of the observed criteria as a function of $d_{j}(a, b)$. The following restrictions should be kept in mind: $<P_{j}(a, b)<1$ and $P_{j}(a, b) \neq P_{j}(b, a)$.

3. After the calculation of the preference level for each pair of the alternatives, the general index of the preferences of the alternative $a$ in comparison with the alternative $b$ is calculated:

$$
\forall a, b \in A \pi(a, b)=\sum_{j=1}^{k} P_{j}(a, b) w_{j}
$$

where $\pi(a, b)$ represents the weighted sum of $P_{j}(a, b)$ for each criteria, while $w_{j}$ is the weight coefficient of the $j$ criteria.

4. The next step implies the calculation of the positive and the negative preference flows:

$$
\varphi^{+}(a)=\frac{1}{m-1} \sum_{x \in A} \pi(a, b)
$$

$$
\varphi^{-}(a)=\frac{1}{m-1} \sum_{x \in A} \pi(b, a)
$$

where $\varphi^{+}$represents the positive preference flow and shows the extent to which the alternative $a$ is better in comparison with all the other alternatives, and $\varphi^{-}$stands for the negative preference flow, which indicates the extent to which an alternative is inferior to the other alternatives. These flows are calculated for each alternative individually.

5. Based on the calculated positive and negative preference flows, the net preference flow is calculated:

$$
\varphi(a)=\varphi^{+}(a)-\varphi^{-}(a)
$$

where $\varphi(a)$ represents the net preference flow for each alternative. In accordance with its value, the final ranking of the alternative is performed. The value of the net preference flow ranges from -1 to +1 , where the bestranked alternative will have the largest positive net flow of preferences, and the worst-ranked alternative will have the biggest negative net flow preference.

\subsection{Entropy Method}

An effective multi-criteria decisionmaking problem solving requires an adequate approach to the determination of weight coefficients because they may greatly affect the ranking of alternatives. Weight coefficients can be defined subjectively and objectively, depending on the source of information for their definition (Hwang \& Lin, 1987). Subjectively determined weight coefficients reflect decision-makers' subjective attitudes based on their preferences and obtained through interviews, 
surveys and organized meetings. Objective weight coefficients are those obtained on the basis of objective information, such as the decision matrix (Chen \& Li, 2011). Bearing in mind the fact that the topic of this paper is an analysis of a macroeconomic problem, where the comparative analysis of the business economy of certain groups of enterprises should be performed objectively, it is more appropriate to use an objective approach to defining weight coefficients. One of the most commonly used methods for the objective determination of weight coefficients is the entropy method (Hwang \& Yoon, 1981; Zeleny, 1982; Zou et al., 2006). It was first applied in thermodynamics, after which Shannon introduced it into the theory of information (Shannon, 1984). It is currently used in numerous scientific fields, such as ecology, engineering, medicine, economics, finance and the like (Zou et al., 2006; Chuansheng et al., 2012; Ermatita et. al., 2012; Liu et al., 2004; He \& Shang, 2017).

Information entropy is a measure of the system disorder (Meng, 1989). It allows the measuring of the amount of useful information in the collected data. When there is a high difference among the values of the observed data on a particular indicator entropy is low, indicating that this indicator provides more information and the weight coefficient of this indicator should be higher. On the other hand, if the difference is lower and entropy is higher, the weight coefficient of the indicator will be lower (Qiu, 2002).

The application of entropy method for weight coefficient definition is carried out through several steps:

1. The first step is the normalization of the original evaluation matrix $\mathrm{X}=\left(\mathrm{x}_{\mathrm{ij}}\right)_{\mathrm{mxn}}$

$$
X=\left|\begin{array}{lr}
x_{11}, x_{12}, \cdots & x_{1 n} \\
x_{21}, x_{22}, \cdots & x_{2 n} \\
x_{m 1}, x_{m 2}, \cdots & x_{m n}
\end{array}\right|
$$

2. In the next step, normalization of this matrix enable formulation of the equation:

$$
R=\left(r_{i j}\right)_{m x n}
$$

where rij is the data of the $\mathrm{i}$-th observed case of the $\mathrm{j}$-th indicator, whereby $r_{i j} \in[0,1]$;

3. For the indicators that should be maximized, the following equation is applied:

$$
\begin{gathered}
r_{i j}=\frac{x_{i j}-\min \left\{x_{i j}\right\}}{\max _{j}\left\{x_{i j}\right\}-\min _{j}\left\{x_{i j}\right\}} \\
i=1 \ldots m ; j=1 \ldots n
\end{gathered}
$$

while indicators that should be minimized require application of following equation:

$$
\begin{gathered}
r_{i j}=\frac{\max _{j}\left\{x_{i j}\right\}-x_{i j}}{\max _{j}\left\{x_{i j}\right\}-\min _{j}\left\{x_{i j}\right\}} \\
i=1 \ldots m ; j=1 \ldots n
\end{gathered}
$$

4. The next step consists of the entropy calculation. In the case of $n$ indicators and $m$ evaluating objects of evaluation problem, the entropy of $j$-th indicator is defined as:

$$
H_{j}=-k \sum_{i=1}^{m} r_{i j} \ln r_{i j}, j=1,2, \ldots, n
$$

where $k=1 / \ln m$ and implies that $r_{i j}=0$, $\ln r_{i j}=0$. 
5. Finally, the last step is the calculation of the weight of entropy. The weight of entropy of $\mathrm{j}$-th indicator is calculated as:

$$
w_{j}=\frac{d j}{\sum_{j=1}^{n} d j}=\frac{1-H_{j}}{\sum_{j=1}^{n}\left(1-H_{j}\right)}
$$

where $d_{j}=1-H_{j}$ is the degree of diversification for $j$-th indicator $(j=1 \ldots n)$ and $0 \leq w_{j} \leq 1, \sum_{j=1}^{n} w_{j}=1$.

\subsection{The Selection of Ranking Indicators}

Having in mind a large number of the ratios used for the assessment of the different aspect of business doing in large enterprises, it is necessary to reduce the number of the indicators which would be used for ranking and to carefully select a set of the indicators which will best reflect the analyzed problem. The correct choice of indicators is vital because it greatly influences the final research results (Hellwig, 1974). In order to assess the level of the differentiation of the variables, the coefficient of variation and Pearson's correlation coefficient were used.
The variable will be included in the consideration if the coefficient of variation is higher than $10 \%$, and the correlation coefficient between the pairs of the indicators is lower than 0.7 (Fura et al., 2017). Both coefficients are calculated for the data from 2014 and 2017. The variation coefficient was less than $10 \%$ in all the three cases only for the efficiency coefficient, which was then eliminated. The next step was to calculate the correlation coefficient between the pairs of the indicators in each group. The results are shown in Table 6 and Table 7.

Based on the data from these two tables, the following indicators were selected: the current ratio, the customer turnover coefficient, the fixed assets turnover, ROA and the debt ratio. The current ratio was selected as the most used liquidity indicator amongst the three analyzed indicators in the group since in both cases the correlation coefficient was higher than 0.7 for all the pairs of the indicators. Table 6 and Table 7 show that the correlation coefficient was lower than 0.7 for the customer turnover coefficient, the average collection period and

Table 6. The correlation coefficients for the pairs of the indicators in each group of the ratio indicators in 2014

\begin{tabular}{|l|c|c|c|c|c|c|c|c|c|c|c|c|c|}
\cline { 2 - 17 } \multicolumn{1}{c|}{} & CR & QR & NWC & CTC & ACP & FAT & AT & OPM & NPM & ROA & ROE & DR & DER \\
\hline CR & 1 & & & & & & & & & & & & \\
\hline QR & 0,98 & 1 & & & & & & & & & & & \\
\hline NWC & 0,99 & 0,96 & 1 & & & & & & & & & & \\
\hline CTC & & & & 1 & & & & & & & & & \\
\hline ACP & & & & $-1,00$ & 1 & & & & & & & & \\
\hline FAT & & & & 0,24 & $-0,28$ & 1 & & & & & & & \\
\hline AT & & & & 0,69 & $-0,72$ & 0,86 & 1 & & & & & & \\
\hline OPM & & & & & & & & 1 & & & & & \\
\hline NPM & & & & & & & & 0,91 & 1 & & & & \\
\hline ROA & & & & & & & & 0,87 & 0,97 & 1 & & & \\
\hline ROE & & & & & & & & 0,95 & 0,92 & 0,82 & 1 & & \\
\hline DR & & & & & & & & & & & & 1 & \\
\hline DER & & & & & & & & & & & & 0,40 & 1 \\
\hline
\end{tabular}

Source: Authors' calculations 
Table 7. The correlation coefficients for the pairs of the indicators in each group of the ratio indicators in 2017

\begin{tabular}{|c|c|c|c|c|c|c|c|c|c|c|c|c|c|}
\hline & CR & QR & NWC & CTC & $\mathrm{ACP}$ & FAT & AT & OPM & NPM & ROA & ROE & DR & DER \\
\hline CR & 1 & & & & & & & & & & & & \\
\hline QR & 0,99 & 1 & & & & & & & & & & & \\
\hline NWC & 0,98 & 0,98 & 1 & & & & & & & & & & \\
\hline CTC & & & & 1 & & & & & & & & & \\
\hline ACP & & & & $-0,99$ & 1 & & & & & & & & \\
\hline FAT & & & & 0,19 & $-0,33$ & 1 & & & & & & & \\
\hline AT & & & & 0,61 & $-0,72$ & 0,89 & 1 & & & & & & \\
\hline OPM & & & & & & & & 1 & & & & & \\
\hline NPM & & & & & & & & 0,98 & 1 & & & & \\
\hline $\mathrm{ROA}$ & & & & & & & & 0,91 & 0,83 & 1 & & & \\
\hline ROE & & & & & & & & 0,95 & 0,93 & 0,96 & 1 & & \\
\hline DR & & & & & & & & & & & & 1 & \\
\hline DER & & & & & & & & & & & & 0,95 & 1 \\
\hline
\end{tabular}

Source: Authors' calculations

Table 8. The multi-criteria analysis parameters for 2014

\begin{tabular}{cccccc}
\hline & CR & CTC & FAT & ROA & DR \\
\hline Direction of preference & $\max$ & $\max$ & $\max$ & $\max$ & $\min$ \\
\hline Weight coefficient & 0,2110 & 0,1963 & 0,2116 & 0,1760 & 0,2050 \\
Preference function & Linear & Linear & Linear & Linear & Linear \\
Q & 0,08 & 0,89 & 0,24 & 1,05 & 12,04 \\
P & 0,24 & 2,12 & 0,75 & 2,98 & 30,54 \\
\hline
\end{tabular}

Source: Authors' calculations

fixed assets turnover. The combination of the customer turnover coefficient and fixed assets turnover is chosen because the lowest correlation coefficient is recorded for this pair of the indicators in both cases. As for the profitability indicators, the high correlation coefficient is recorded for all the pairs of the indicators, so the authors decided to choose ROA as the most used indicator in practice. Finally, in the group of the debt indicators in Table 6, the correlation coefficient is lower than 0.7 , whereas in Table 7 this coefficient is much higher, suggesting that one indicator should be selected. The authors chose the debt ratio as the debt-to-equity ratio was negative in some cases (due to the loss above equity), so the results might be illogical (the economic entities are trying to reduce this indicator, so the enterprises with a negative debt-to-equity ratio will be preferred over the others).

\subsection{The Multi-Criteria Model Formulation}

After the criteria had been selected, the parameters for both observed years should be defined. Table 8 shows the multi-criteria model formulation for the ranking of the business entities by size in 2014 .

Table 8 shows that all the indicators, except the debt ratio, should be maximized. 
The weight coefficients shown in Table 7 were obtained by the entropy method. The values of the weight coefficients suggest that the greatest differences between the groups of enterprises by their size can be seen for the fixed assets turnover, as it is exactly here that the highest weight coefficients were obtained. The high variations are recorded for the current ratio as well, where the weight coefficient was somewhat lower. Nonetheless, the lowest weight coefficient, and, thus, the most similar situation in all the groups of the business entities, was seen for ROA. The Visual PROMETHEE Software Package proposed a linear function with the appropriate values of preference and indifference thresholds for all the indicators.

The same parameters were defined for the ranking of the economic entities in 2017, and they are presented in Table 9.

Table 9 shows that the direction and function of the preferences remained the same, and the weight coefficients differed due to the different data range for the observed groups of the business entities. The greatest differences are present in fixed assets turnover, so this indicator has the highest weight coefficient, whereas the lowest weight coefficient was obtained for ROA.

\section{RESULTS AND DISCUSSION}

Based on the defined multi-criteria parameters, the ranking of certain groups of the business entities by size was performed by the Visual PROMETHEE Program (Academic Edition).

In order to perform the comparative analysis of the business economy in large, medium-sized, small and micro-economic entities, the ranking was performed by using the PROMETHEE II method. The obtained results are shown in Table 10.

Based on the results from Table 10, the medium-sized companies had the most favorable business economy in 2014 according to all of the selected ratio indicators. They were followed by the large,

Table 9. The multi-criteria analysis parameters for 2017

\begin{tabular}{cccccc}
\hline & CR & CTC & FAT & ROA & DR \\
\hline Direction of preference & $\max$ & $\max$ & $\max$ & $\max$ & $\min$ \\
\hline Weight coefficient & 0,2045 & 0,1790 & 0,2501 & 0,1715 & 0,1949 \\
Preference function & Linear & Linear & Linear & Linear & Linear \\
$\mathrm{Q}$ & 0,12 & 1,05 & 0,33 & 1,27 & 13,83 \\
$\mathrm{P}$ & 0,34 & 2,81 & 0,94 & 3,58 & 35,96 \\
\hline
\end{tabular}

Source: Authors' calculations.

Table 10. The ranking of the business entities by size in 2014

\begin{tabular}{ccrrr}
\hline Rang & Business entities by their size & Phi+ & \multicolumn{1}{c}{ Phi- } & \multicolumn{1}{c}{ Phi } \\
\hline 1 & Medium & 0,3358 & 0,1353 & 0,2006 \\
2 & Large & 0,2876 & 0,0975 & 0,1901 \\
3 & Small & 0,2197 & 0,099 & 0,1207 \\
4 & Micro & 0,079 & 0,5904 & $-0,5114$ \\
\hline
\end{tabular}

Source: Authors' calculations 
small and micro-business entities, respectively. The micro-business entities occupied the most disadvantageous position because only they had a negative net preference flow.

In order to understand which aspect of the business operations had the greatest influence on such an order of the economic entities, Figure 1 shows the advantages and the limitations of the observed group of the business entities.

The data in Figure 1 show that the medium-sized enterprises are best ranked in 2014 due to the significant advantage in all of the considered criteria, except for the fixed assets turnover. The large and small business entities also had one limitation. In the case of the large enterprises, the limitation is reflected in the current ratio, whereas for the small enterprises, it is the fixed assets turnover. The better position of the large enterprises over the small ones is a result of a more favorable fixed asset turnover (which is a significant advantage for the large enterprises, but rather a disadvantage in the small enterprises) and the debt ratio. Finally, the micro-business entities ranked worst since all the analyzed aspects of the business economy, except for the fixed assets turnover, represented the serious limitations for the business operations of these economic entities.

In order to gain an insight into the changes in the business economy of the observed group of the companies, the ranking for 2017 was performed and the ranking results are shown in Table 11 .

The results in Table 11 show that the best business economy was that recorded in the large economic entities, only to be followed by the small, medium-sized and microcompanies. As in 2014, only the microenterprises had a negative net preference flow. As can be seen, there are significant

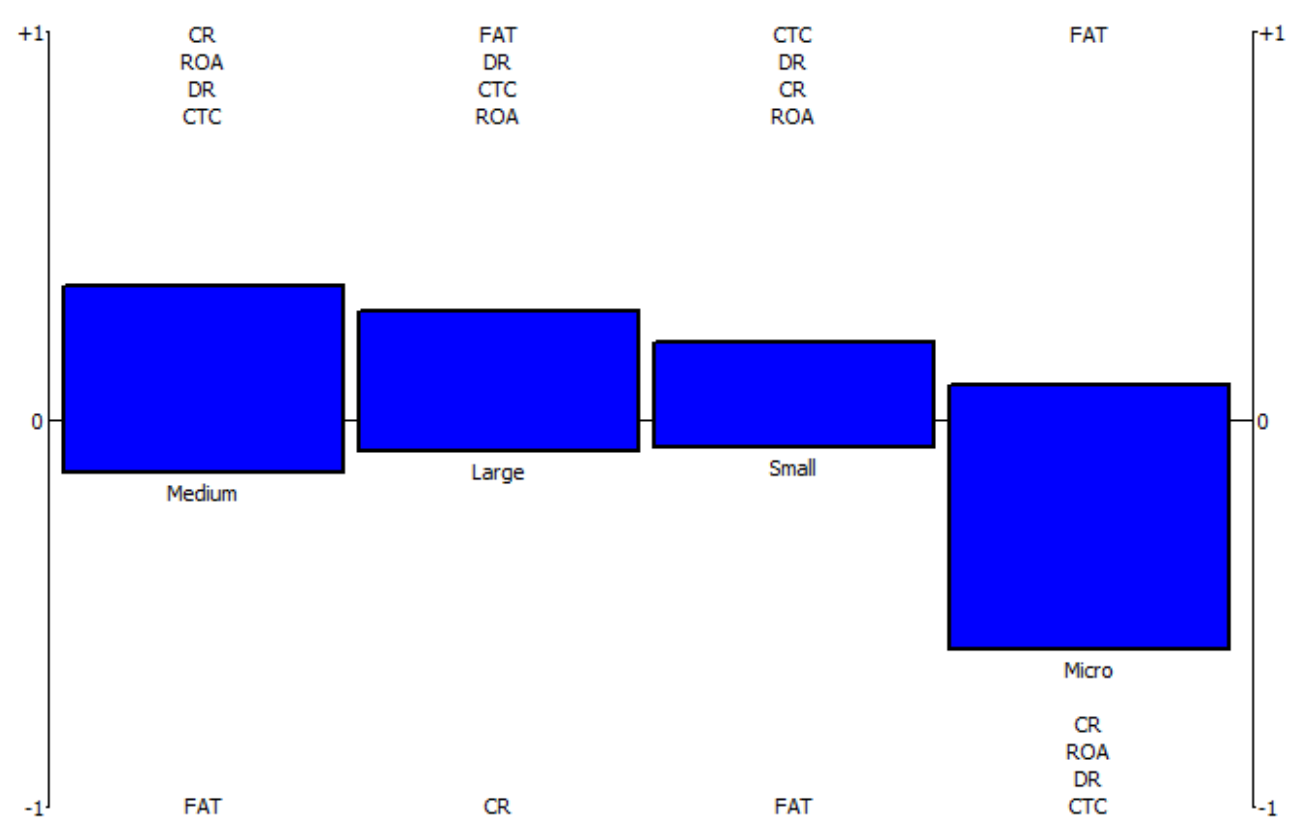

Figure 1. The advantages and the limitations of the observed groups of the business entities in 2014 
changes in the order of the observed business entities. In order to identify the factors that caused these changes, the key advantages and limitations of the observed business entities in 2017 are shown in Figure 2.

Based on Figure 2, it can be concluded that the large enterprises had the advantage over the other business entities in the other regions according to all of the analyzed ratio indicators, expect for the current ratio. The small and medium enterprises also had one limitation - their fixed assets turnover. This is exactly the main reason for the favorable position of the large enterprises in comparison with the small and the medium ones. For the worst-ranked business entities - the microenterprises, all of the analyzed aspects were seen as serious limitations, except for the fixed assets turnover.

\section{CONCLUSION}

In the era of intensified globalization and internationalization, large enterprises represent the main drivers of the technological development and economic growth. This is particularly true for transition economies, where the SMEs sector is still weak and insufficiently developed to compensate for the

Table 11. The ranking of the business entities by size in 2017

\begin{tabular}{ccccc}
\hline Rang & Business entities by their size & Phi+ & Phi- & \multicolumn{1}{c}{ Phi } \\
\hline 1 & Large & 0,3055 & 0,0738 & 0,2317 \\
2 & Small & 0,2409 & 0,0886 & 0,1523 \\
3 & Medium & 0,2639 & 0,1728 & 0,0911 \\
4 & Micro & 0,1204 & 0,5955 & $-0,4751$ \\
\hline Source: Authors' calculations.
\end{tabular}

Source: Authors' calculations.

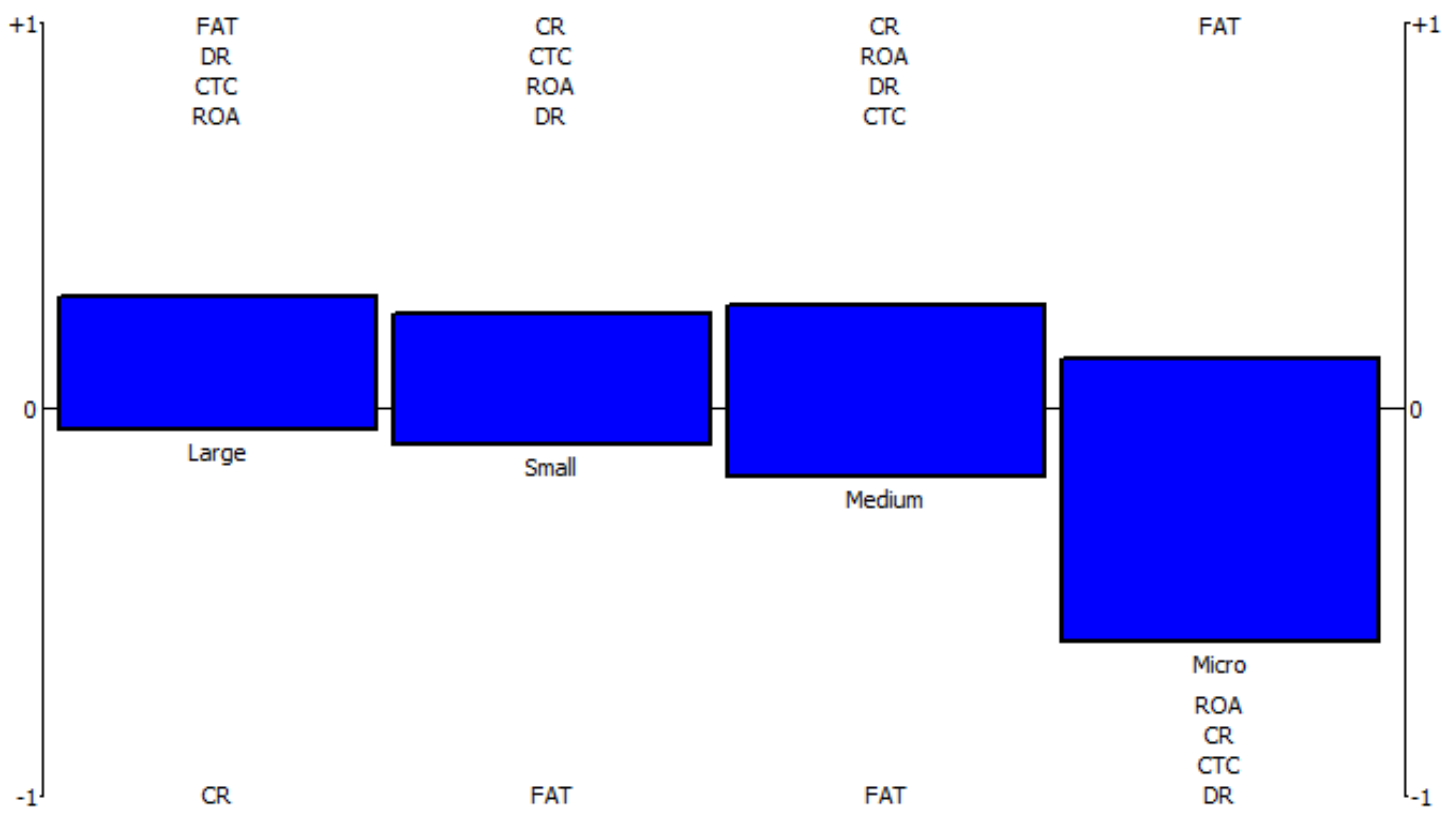

Figure 2. The advantages and the limitations of the observed groups of the business entities in 2017 
decline in the economic activity caused by the privatization and restructuring of public enterprises. Such a situation is present in Republic of Serbia. The transition processes have greatly influenced the structure of the Serbian economy. The number of SMEs has significantly increased during the last two decades, whereas the number of large enterprises has reduced. However, large enterprises still have a dominant share in employment, the production capacities of the economy and generated income.

During the period 2014-2017, large enterprises significantly improved their liquidity, assets management and profitability, their leverage simultaneously deteriorating. These developments improved their position in the rankings. They shifted from the second to the first position in 2017 , and they are followed by small, mediumsized and, at the very end, micro-enterprises. The increase in fixed assets turnover was the main factor enabling them to take a more favorable position, which is not surprising having in mind the fact that these enterprises achieve significant advantages from the economy of scale. Their investments in production capacities are cost-effective because they generate high income from sale.

Ultimately, it should be emphasized that there is still room for progress in the field of liquidity and debt management in the future period. Improvements in these areas will lead to the long-term sustainable growth and development of these enterprises, as well as the economy as a whole.

\section{УЛОГА И ЗНАЧАЈ ВЕЛИКИХ ПРИВРЕДНИХ СУБЈЕКАТА У ПРИВРЕДИ РЕПУБЛИКЕ СРБИЈЕ}

\section{Саша Крстић и Александра Федајев}

\section{Извод}

Развијене тржишне привреде у савременим условима пословања карактерише све већи значај МСП сектора за развој привреде. У склату с тим, последњих година велики број радова се бавио анализом пословања привредних субјеката у овом сектору. Тиме је у извесној мери померен фокус са великих привредних субјеката и њиховог значаја за привредни раст на МСП сектор. С тим у вези, циљ овог рада је да се испита финансијско стање, место и улога великих привредних субјеката у привреди Републике Србије, у којој, с обзиром да се ради о транзиционој привреди, велике компаније, како приватне, тако и јавне, значајно доприносе расту привредне активности и запослености. Применом рацио анализе, најпре је утврђен ниво ликвидности, ефикасности, задужености и профитабилности ових компанија у периоду 20142017. године. Након тога је на основу одабраних рациа, применом ентропијске и PROMETHEЕ II методе, извршена је компаративна анализа финансијских перформанси великих привредних субјеката у односу на мала, средња и микро. Добијени резултати указују на то да велики привредни субјекти имају повољну економију пословања у односу на остале групе привредних субјеката по величини, а њихове перформансе су у извесној мери побољшане у посматраном периоду.

Кључне речи: велика привредна друштва, рацио анализа, ентропијска метода, PROMETHEE II метода 


\section{References}

Accounting law, 2013. https://www.paragraf.rs/propisi/zakon_o_rac unovodstvu.html

Andreopoulou, Z., Koliouska, C., Galariotis, E., \& Zopounidis, C. (2018). Renewable energy sources: Using PROMETHEE II for ranking websites to support market opportunities. Technological Forecasting \& Social Change, 131, 31-37.

Anđelković, A. (2017). Guerrilla Marketing - A Technique of Increasing Competitiveness of Small and Medium Enterprises. Annals of the Faculty of Economics in Subotica, 37, 101-115.

Aničić, J., Aničić, D, \& Vasić N. (2017). Entrepreneurship development and financial performances in SMEs sector in Serbia. Economy, 63 (4), 29-39.

Araz, C., \& Ozkarahan, I. (2007). Supplier evaluation and management system for strategic sourcing based on a new multicriteria sorting procedure. International Journal of Production Economics, Elsevier, 106 (2), 585-606.

Brans, J.P. \& Mareschal, B. (2005). Promethee methods. Chapter 5 in: Multiple Criteria Decision Analysis: State of the Art Surveys, Springer Science and Business Media, Boston, p. 170.

Brans, J.P. Mareschal, \& B. Vincke, Ph. (1984). PROMETHEE: A new family of outranking methods in multi-criteria analysis, in Brans, J.P. (Ed.), Operational Research '84, North-Holland, Amsterdam, pp. 447-490

Brans, J.P., \& Vincke, B. (1985). A preference ranking organisation method: The PROMETHEE method for MCDM. Management Science, 3 (6), 647-656.

Březinovă, M., \& Průšovă J. (2014). Small and mediu-sized enterprises in terms of their goals. Megatrend Magazine, 11 (3), 145-154.

Chen, T.Y. \& Li, C.H. (2011). Objective Weights with Intuitionistic Fuzzy Entropy Measures and Computational Experiment Analysis. Applied Soft Computing, 11 (8), 5411-5423.

Chuansheng, X., Dapeng, D., Shengping, H., Xin, X., \& Yingjie, C. (2012). Safety Evaluation of Smart Grid based on AHPEntropy Method. Systems Engineering Procedia, 4, 203-209.

Đalić, I., Terzić, S., \& Novarlić, B. (2017). The role of venture capital in the development of the SME sector. The European Journal of Applied Economics, 14 (2), 58-692.

Ermatita, Hartati, S., Wardoyo, R., \& Harjoko, A. (2012). ELECTRE-Entropy method in Group Decision Support System Modelto Gene Mutation Detection. International Journal of Advanced Research in Artificial Intelligence, 1 (1), 58-63.

Filipović, M., \& Mirjanić, B. (2016) Financial analysis and credit slovency evaluation of a selected enterprise case study of a company „Ačeva Novi Kneževac“. Economics: Theory and Practice, 9 (3), 1631.

Fura, B., Wojnar, J., \& Kasprzyk, B. (2017). Ranking and classification of EU countries regarding their levels of implementation of the Europe 2020 strategy. Journal of Cleaner Production, 165, 968-979.

He, J., \& Shang, P. (2017). Comparison of transfer entropy methods for financial time series. Physica A: Statistical Mechanics and Its Applications, 482, 772-785.

Hellwig, Z. (1974). A method for the selection of a "compact" set of variables. Reports and papers in social sciences. Social Indicators: Problems of Definition and of Selection, 30, 11-20. 
Hwang, C.L., \& Lin, M.J. (1987). Group Decision Making under Multiple Criteria: Methods and Applications. Berlin, DE: Springer Verlag.

Hwang, C.L., \& Yoon, K. (1981). Multiple Attribute Decision MakingMethods and Applications. A State-of-theArt Survey. New York, US: Springer Verlag.

Ishizaka, A., \& Nemery, P. (2013). MultiCriteria Decision Analysis: Methods and Software. New Jersey, US:John Wiley Sons, Ltd. Hoboken

Jakopin, E. (2015). Regional drivers of economic growth. Business Economy, 63 (12), 99-113.

Kastratović, (2016). The Influence of Foreign Direct Investments on Economic and Social Development of Serbia. Bankarstvo, 45 (4), 70-93.

Liu, Q., Wang, S., Zhang, W., Li, J., Zhao, Y., \& Li, W. (2017). China's municipal public infrastructure: Estimating construction levels and investment efficiency using the entropy method and a DEA model. Habitat International, 64, 59-70.

Lopes, A.P.F., Muñoz, M.M., \& AlarcónUrbistondo, P., (2018). Regional tourism competitiveness using the PROMETHEE approach. Annals of Tourism Research, 73, $1-13$.

Marasovic, B., \& Babic, Z., (2011). Twostep multi-criteria model for selecting optimal portfolio. International Journal of Production Economics, 134 (1), 58-66.

Meng, Q.S. (1989). Information Theory [M]. Xi'An, CN: Xi'An Jiaotong University Press, 19-36.

Ministry of economy in Republic of Serbia, http://www.priv.rs/Ministry-ofEconomy/211/Privatization.shtml accessed on December 20, 2018.

Nikolić, R., \& Fedajev, A. (2016) Business economy. Vrnjačka Banja, Civil library Europe (In Serbian)

Paunović, G. (2017). The role of small and medium enterprises and entrepreneurship in the development of national economies. Economics: Theory and Practice, 10 (1), 44-63.

Qiu W.H., (2002). Management Decision and Applied Entropy Theory, Beijing, CN: China Machine Press, Beijing.

Shannon, C. E. (1984). A Mathematical Theory of Communication. The Bell System Technical Journal, 27 (3), 379-423

Stojanović, D. (2018). Foreign direct investments, export and economic growth in the Serbia. Business Economics, 12 (1), 5472 .

Tomić-Plazibat, N., Aljinović, Z., \& Pivac, S. (2010). Risk Assessment of transitional Economies by multivariate and Multicriteria Approaches. Panoeconomicus, 57 (3), 283-302.

VP Solutions, Visual PROMETHEE, http://www.promethee-gaia.net/files/ VPManual.pdf accessed on December 29, 2018.

Zeleny, M. (1982). Multiple Criteria Decision Making. New York. US: McGrawHill.

Zou, Z., Yun, Y., \& Sun, J. (2006). Entropy Method for Determination of Weight of Evaluating Indicators in Fuzzy Synthetic Evaluation for Water Quality Assessment. Journal of Environmental Sciences, 18 (5), 1020-1023. 